\title{
REGIO- AND STEREOSELECTIVE RING-OPENING REACTIONS OF CYCLOPROPENONES: $\alpha$-METHYLENE- $\gamma$-BUTYROLACTONES VIA ADDITIONS OF TRICHLOROCYCLOPROPENYLIUM IONS TO ALKENES
}

\author{
Klaus Musigmann and Herbert Mayr* \\ Institut für Chemie der Medizinischen Universität zu Lübeck \\ Ratzeburger Allee 160, D-2400 Lübeck 1, Federal Republic of Germany \\ Armin de Meijere ${ }^{1}$ \\ Institut für Organische Chemie der Universität Hamburg \\ Martin-Luther-King-Platz 6, D-2000 Hamburg 13, Federal Republic of Germany
}

\begin{abstract}
The 2-chloro-3-(2'-chloroalkyl)cyclopropenones 4, readily obtained by hydrolysis of the adducts of the trichlorocyclopropenylium ion onto alkenes, thermally rearrange to propiolic acid chlorides 6. Treatment of 4 with TosOH. $\mathrm{H}_{2} \mathrm{O}$ in $\mathrm{CH}_{2} \mathrm{Cl}_{2}$ yields the (E)-3-chloro-2-(2'-chloroalkyl)acrylic acids 9, which have been converted in two simple steps to $\alpha$-methylene- $\gamma$-butyrolactones 11 with good overall yields.
\end{abstract}

Trichlorocyclopropenylium (1) salts usually react with alkenes 2 to give [1:2]- and [1:3]-products, ${ }^{2}$ but in nitromethane solution, the selective formation of the [1:1]-adducts 3 has been accomplished. ${ }^{3}$ The hydrolysis of 1-substituted trichlorocyclopropenes like 3 has been found to give the chlorocyclopropenones $4 .^{3,4}$

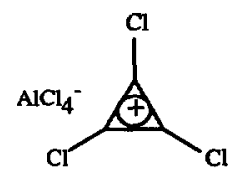

1
1)

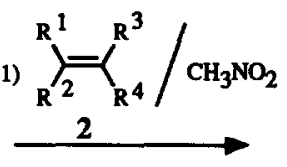

2) LiCl

40-76\%

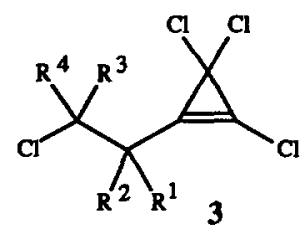

3
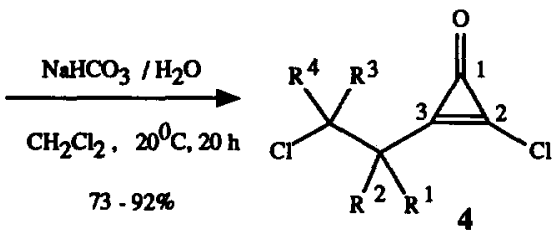

In this communication we report conditions to selectively cleave the $\mathrm{C}-1 / \mathrm{C}-3$ bond or the $\mathrm{C}-1 / \mathrm{C}-2$ bond of 4 , and we describe a novel access to $\alpha$-methylene- $\gamma$-butyrolactones 11. 
The 2-chloro-3-(2'-chloroalkyl)cyclopropenones 4 were obtained in 73-92\% yield, when solutions of 3 in $\mathrm{CH}_{2} \mathrm{Cl}_{2}$ were stirred with aqueous $\mathrm{NaHCO}_{3}$ solutions at ambient temperature. This procedure usually gives better yields than treatment of the neat trichlorocyclopropenes 3 with aqueous $\mathrm{NaHCO}_{3}{ }^{3}$ Compounds 4 partially isomerize to the acid chlorides 6 when kept at room temperature for several days. An acceleration of this process by chloride ions $\left(\mathrm{R}_{4} \mathrm{~N}^{+} \mathrm{Cl}^{-}\right)$has not been found, but complete rearrangements of 4 to 6 were achieved (isolated yields: 75-90\%) when neat samples of 4 were heated at $100^{\circ} \mathrm{C}$ for $1 \mathrm{~h}$. Though the carbenes 5 may be intermediates in this isomerisation, ${ }^{4,5}$ we prefer a mechanism, in which migration of $\mathrm{Cl}$ begins, before the cleavage of the C-1/C-3 bond in 4 is complete.

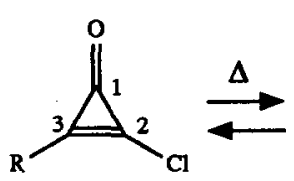

4<smiles>[R]CC(=O)C(Cl)CC</smiles>

$$
R=-C R^{1} R^{2}-C R^{3} R^{4} C l
$$<smiles>[R]C(C)=C1CCCCC1CCC</smiles>

$\mathbf{5}$<smiles>[R]C#CC(=O)Cl</smiles>

6

Selective cleavage of the other single bond (C-1/C-2) in the cyclopropenone ring can be accomplished under acidic conditions, e. g. by stirring $4 \mathrm{a}-\mathrm{f}$ with $\mathrm{TosOH} \cdot \mathrm{H}_{2} \mathrm{O}$ in $\mathrm{CCl}_{4}$ at room temperature to produce single diastereoisomers of the acrylic acids 9a-f. Their $(E)$-configuration has been derived from the coupling constant of $5.2 \mathrm{~Hz}$ between the vinylic hydrogen and the carbonyl carbon of $9 \mathrm{e}\left({ }^{3} \mathrm{~J}_{\mathrm{C}, \mathrm{H}}\right)$. In analogy to this finding, 2-aryl-3-chlorocyclopropenones have been reported to yield (E)-2-aryl-3-chloroacrylic acids, ${ }^{6 a}$ and in one case the configuration of the resulting 3-chloroacrylic acid has been corroborated by X-ray structure analysis. ${ }^{6 \mathrm{~b}}$ Since alkyl groups are better electron donors than chlorine, initial protonation of 4 can be assumed to preferably take place at $\mathrm{C}-2$, and the electrocyclic ring opening of the cyclopropyl cation 7 may then yield the allyl cation 8 , the precursor of 9 . The stereoselective formation of the $(E)$-configurated allyl cation 8 may be rationalized in a similar way as the ionisation of cyclopropyl derivatives under solvolytic conditions, in which the loss of the nucleofugal group is supported by the exo-disrotatory ring opening mode. ${ }^{7}$ Analogously, one might assume that the rotation of the $\mathrm{C}-2 / \mathrm{C}-3$ bond is initiated before protonation of 4 is complete, in which case 7 would not be an intermediate. ${ }^{8}$<smiles>[R][Y10]#[Z10][H]</smiles>

$4 \quad \mathrm{R}=-\mathrm{CR}^{1} \mathrm{R}^{2}-\mathrm{CR}^{3} \mathrm{R}^{4} \mathrm{CI}$ 7 
Treatment of the (E)-3-chloro-2-(2'-chloroalkyl)acrylic acids 9 with $\mathrm{AgNO}_{3}$ in aqueous tetrahydrofuran 9 yields the $\alpha$ - $(E)$-chloromethylene- $\gamma$-butyrolactones 10 which can be dehalogenated with activated zinc powder in methanol ${ }^{10}$ to give $\alpha$-methylene- $\gamma$-butyrolactones 11 (see Table 1 and Scheme 1). Because of their interesting biological activities such compounds are presently under intensive investigation. ${ }^{11-13}$<smiles>[Y4]C([R4])(Cl)C([R2])([Y3])c1c(Cl)c1=O</smiles>

4a-f<smiles>[R4]C([R4])(Cl)C([R])([R])C(=CCl)C(=O)O</smiles>

9a-f

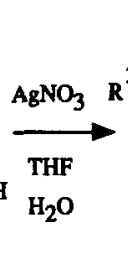

$\underset{\mathrm{THF}}{\longrightarrow}$

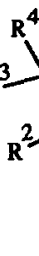

$\mathbf{R}^{4}$

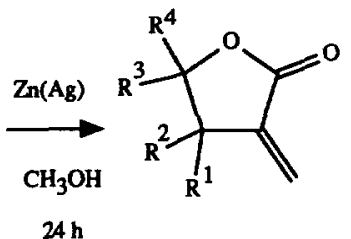

11a-f

Table 1. Synthesis of the $\alpha$-Methylene- $\gamma$-butyrolactones 11a-f from 1 and the Alkenes 2a-f.

\begin{tabular}{|c|c|c|c|c|c|c|c|c|c|c|c|}
\hline & $\mathbf{R}^{1}$ & $\mathbf{R}^{2}$ & $\mathbf{R}^{3}$ & $\mathbf{R}^{4}$ & $1+2 a-f \rightarrow 3 a-f$ & $\rightarrow$ & 4a-f & $\rightarrow$ & 9a-f & $\rightarrow$ 10a-f & $\rightarrow$ 11a-f \\
\hline $\mathbf{a}$ & $\mathrm{H}$ & $\mathrm{CH}_{3}$ & $\mathrm{CH}_{3}$ & $\mathrm{CH}_{3}$ & $61 \%$ & $73 \%$ & & $73 \%$ & & $61 \%$ & $81 \%$ \\
\hline b & $\mathrm{H}$ & $\mathrm{C}_{2} \mathrm{H}_{5}$ & $\mathrm{CH}_{3}$ & $\mathrm{CH}_{3}$ & $66 \%$ & $82 \%$ & & $78 \%$ & & $76 \%$ & $77 \%$ \\
\hline c & $\mathrm{H}$ & & $\left.\mathrm{H}_{2}\right)_{4}-$ & $\mathrm{CH}_{3}$ & $54 \%$ & $92 \%$ & & $48 \%$ & & $63 \%$ & $78 \%$ \\
\hline d & $\mathbf{H}$ & $\mathbf{C H}_{\mathbf{3}}$ & $-(C)$ & $\left.z_{2}\right)_{5}$ & $64 \%$ & $85 \%$ & & $43 \%$ & & $78 \%$ & $82 \%$ \\
\hline $\mathbf{e}$ & $\mathrm{CH}_{3}$ & $\mathrm{CH}_{3}$ & $\mathrm{CH}_{3}$ & $\mathrm{CH}_{3}$ & $76 \%$ & $82 \%$ & & $92 \%$ & & $68 \%$ & $80 \%$ \\
\hline $\mathbf{f}$ & $\mathrm{CH}_{3}$ & & $\left.\mathrm{H}_{2}\right)_{4^{-}}$ & $\mathrm{CH}_{3}$ & $66 \%$ & $85 \%$ & & $57 \%$ & & $64 \%$ & $80 \%$ \\
\hline
\end{tabular}

Scheme 1. Overall Yields of $\alpha$-Methylene- $\gamma$-butyrolactones 11a-f from 1 and Alkenes 2a-f.

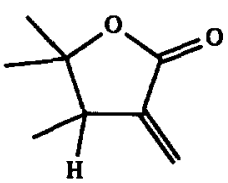

$11 \mathbf{a}^{11 a}(16 \%)$

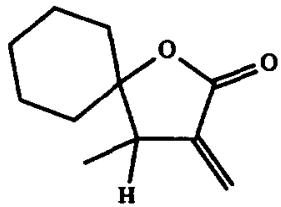

$11 d^{11 a}(15 \%)$

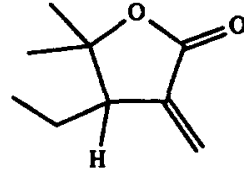

$11 \mathbf{b}(25 \%)$

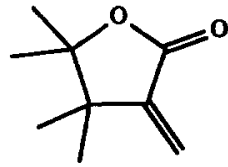

$11 \mathrm{e}^{11 \mathrm{a}, \mathrm{c}}(32 \%)$

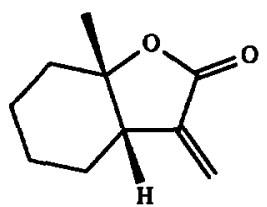

$11 c^{11 a}(12 \%)$

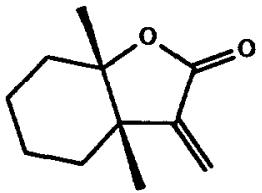

$11 f^{11 d, 14}(16 \%)$ 
As $\alpha$-methylenelactones 11a-f (Scheme 1) are formed in 5 simple steps from 1 and the alkenes $2 \mathrm{a}-\mathrm{f}$ (12-32\% overall yields), 1 may be considered to be a synthetic equivalent for the dipolar synthon 12 .

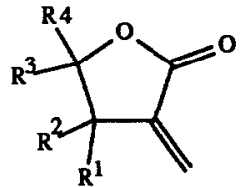

11

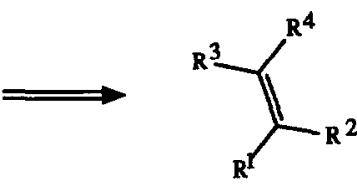

2

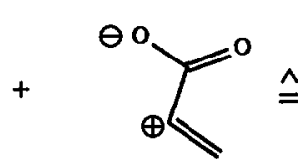

12

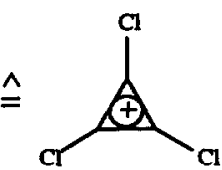

1

This work was supported by the Deutsche Forschungsgemeinschaft and the Fonds der Chemischen Industrie as well as Hoechst $\mathbf{A G}$.

\section{References and Notes.}

(1) New address: Institut für Organische Chemic, Georg-August-Universität Göttingen, Tammannstrasse 2, D-3400 Göttingen, Federal Republic of Germany.

(2) (a) West, R. Accounts Chem. Res. 1970, 3, 130. (b) Weiss, R; Kölbl, H; Schlierf, C. J. Org. Chem. 1976, 41, 2258. (c) Bauer, C.; Le Goff, E. Synthesis 1970, 544.

(3) Musigmann, K.; Mayr, H.; de Meijere, A. Tetrahedron Lett. 1987, 28, 4517.

(4) Reviews on cyclopropenones: (a) Eicher, T; Weber, J. L. Topics Curr. Chem. 1975, 1. (b) Potts, K. T.; Baum, J. S. Chem. Rev. 1974, 74, 189.

(5) For a theoretical study of cyclopropene isomerisations see: Yoshimine, M.; Pacansky, J.; Honjou, N. J. Am. Chem. Soc. 1989, 111, 4198 and references cited therein.

(6) (a) West, R.; Zecher, D. C.; Tobey, S. W. J. Am. Chem. Soc. 1970, 92, 168. (b) Weber, W; Behrens, U; de Meijere, A. Chem. Ber. 1981, 114, 1196.

(7) (a) DePuy, C. H. Accounts Chem. Res. 1968, 1, 33. (b) Scholllkopf, U.; Fellenberger, K; Patsch, M; Schleyer, P. v. R. Tetrahedron Lett. 1967, 3639. (c) Schleyer, P. v. R.; Su, T. M. ; Saunders, M.; Rosenfeld, J. C. J. Am. Chem. Soc. 1969, 91, 5174. (d) Schöllkopf, U. Angew. Chem. 1968, 80, 603; Angew. Chem. Int. Ed. Engl. 1968, 7, 588.

(8) Wendisch, D. in Houben-Weyl-Müller "Methaden der Organischen Chemie", 4. Aufl. Bd. 4/3, Georg Thieme Verlag, Stuttgart, 1971, p. 722

(9) Terlinden, R.; Boland, W.; Jaenicke, L. Helv. Chim. Acta 1983, 66, 466.

(10) Clark, R. D.; Heathcock, C. H. J. Org. Chem. 1973, 38, 3658.

(11) (a) Dulcere, J. P.; Mihoubi, M. N.; Rodriguez, J. J. Chem. Soc., Chem. Commun. 1988, 237.

(b) Loffler, A.; Pratt, R. D.; Pucknat, J.; Gelbard, G.; Dreiding, A. S. Chimia 1969, 23, 413.

(c) Hanson, A. W.; McCulloch, A. W.; McInnes, A. G. Can. J. Chem. 1981, 59, 288. (d) Petrzilka, M; Felix, D.; Eschenmoser, A., Helv. Chim. Acta 1973, 56, 2950.

(12) (a) Grieco, P. A. Synthesis 1975, 67. (b) Hoffmann, H. M. R.; Rabe, J. Angew. Chem. 1985, 97, 96; Angew. Chem. Int. Ed. Engl. 1985, 24, 94. (c) Petragnani, N.; Ferraz, H. M. C.; Silva, G. V. J. Synthesis 1986, 157.

(13) References to more recent articles are given in: Fujiwara, T.; Morita, K.; Takeda, T. Bull. Chem. Soc. Jpn. 1989, 62, 1524.

(14) Stereochemical assignment not proven. 